\title{
Assessment of tumour resection margins using optical coherence tomography
}

\author{
Zaid Hamdoon*, Waseem Jerjes, Gordon McKenzie, Amrita Jay, Colin Hopper \\ From 2nd Scientific Meeting of the Head and Neck Optical Diagnostics Society \\ San Francisco, CA, USA. 23-24 January 2010
}

\section{Introduction/aims}

In the treatment of cancer, the fundamental surgical goal is to remove all local malignant disease and leave no residual malignant cells. Studies have demonstrated the benefit of achieving negative resection margins in terms of disease free local recurrence and overall survival. The surgical margins for head \& neck cancer may vary widely depending on the site of disease.

Optical coherence tomography (OCT) is an imaging modality that uses light to determine cross-sectional anatomy in turbid media such as living tissues.

In this study, we used this technology to evaluate resection margins acquired from patients with oral squamous cell cancer (OSCC).

\section{Material/methods}

Twenty-five patients with newly diagnosed T1-T2 OSCC underwent local resection. In the immediate ex-vivo phase, OCT was used to interrogate the surgical margins of these specimens and the results were, then, compared to histopathology. Inter, Intra-observer differences, sensitivity and specificity was calculated.

\section{Results}

The junctional epithelium (between positive and negative margins) can be identified by gradual change in epithelial thickness and basement membrane organisation (integrity) from the normal to pathological. Identified changes in tumour positive margins include hyperkeratinisation, breach of the basement membrane and disorganised epithelial structure. Tumour spread pattern could be identified on the majority of the interrogated tissue. Sensitivity and specificity were calculated and proved to be encouraging.

\footnotetext{
UCL Department of Surgery, University College London Medical School,
} London, UK

\section{Conclusions}

The results from this study are encouraging and suggest the feasibility of using OCT in differentiating between positive and negative surgical margins.

\section{Acknowledgment}

We would like to thank the BAOMS for supporting this research project.

Published: 29 October 2010

\section{doi:10.1186/1758-3284-2-S1-O7}

Cite this article as: Hamdoon et al:: Assessment of tumour resection margins using optical coherence tomography. Head \& Neck Oncology 2010 2(Suppl 1):O7.
Submit your next manuscript to BioMed Central and take full advantage of:

- Convenient online submission

- Thorough peer review

- No space constraints or color figure charges

- Immediate publication on acceptance

- Inclusion in PubMed, CAS, Scopus and Google Scholar

- Research which is freely available for redistribution

Submit your manuscript at www.biomedcentral.com/submit
C Biomed Central 